кандидат мистецтвознавства, доцент кафедри режисури та хореографії Львівського національного університету імені Івана Франка

ORCID 0000-0002-6374-4811

kundys.ruslan@gmail.com

\title{
СТВОРЕННЯ ХОРЕОГРАФІЧНОГО ОБРАЗУ ЗАСОБАМИ ПЛАСТИЧНИХ І ЧАСОВИХ МИСТЕЦТВ
}

Мета статті - розкрити роль просторових і часових мистецтв у створенні хореографічного образу. Дослідити зв'язок образотворчого та музичного мистецтва як невід'ємної складової балетних вистав. Показати взаємозв'язок українського балетного театру, національного фольклору та літератури. Методологія. У дослідженні застосовано комплекс методів, а саме: історичний, порівняльний, типологічний, метод аналізу та узагальнень, описовий, візуальний, художньо-стилістичний (аналіз творчої манери окремих авторів, їхніх шкіл та художніх епох). Завдяки цим методам було досліджено індивідуальну творчу манеру окремих сценографів, композиторів та балетмейстерів, а також синтез та художню стилістику хореографрічних творів. Наукова новизна роботи визначається розкриттям ролі просторових і часових мистецтв у створенні хореографічного образу, зокрема у встановленні глибинного взаємозв'язку образотворчого та музичного мистецтва. У цьому контексті було досліджено індивідуальну творчу манеру та унікальний стиль відомих українських сценографів, композиторів, музикантів та хореографів. Висновки. Створення високопрофесійного хореографічного образу засобами просторових і часових мистецтв є надзвичайно складним творчим процесом. У ньому відчутна співпраця режисера, композитора, сценографа та балетмейстера. У цьому контексті важливе значення посідає не тільки індивідуальна, але й колективна творчість тих митців, які причетні до створення хореографічного образу у відповідності до можливостей та засобів тих видів мистецтв, у рамках яких вони творять. Слід також наголосити на тому, що досконала пластична мова образотворчого мистецтва, поєднана з музичним супроводом та хореографічною пластикою, створює єдиний цілісний образ вистави. Важливими компонентами створення художнього образу є художній стиль і техніка виконання, поєднання традиції та новаторства. Проте дослідження питання, що стосуються проблеми створення хореографічного образу засобами просторових і часових мистецтв ще потребують глибших досліджень та нових наукових підходів.

Ключові слова: хореографічний образ; образотворчі, словесні та музичні мистецтва; сценографрія; балет; народно-сценічний танець.

Демьянчук Андрей Львович, кандидат искусствоведения, доцент кафедры режиссуры и хореографии Львовского национального университета им. Ивана Франко; Кундыс Руслан Юрьевич, кандидат искусствоведения, доцент кафредры режиссуры и хореографии Львовского национального университета им. Ивана Франко

\section{Создание хореографического образа средствами пространственных и временных искусств}

Цель статьи - раскрыть роль пространственных и временных искусств в создании хореографического образа. Исследовать связь изобразительного и музыкального искусства как неотъемлемой составляющей балетных спектаклей. Показать взаимосвязь украинского балетного театра, национального фольклора и литературы. Методология. В исследовании применен комплекс методов, а именно: исторический, сравнительный, типологический, метод анализа и обобщений, описательный, визуальный, художественно-стилистический (анализ творческой манеры отдельных авторов, их школ и художественных эпох). Благодаря этим методам было исследовано индивидуальную творческую манеру отдельных сценографов, композиторов и балетмейстеров, а также синтез и художественную стилистику хореографических произведений. Научная новизна работы определяется раскрытием роли пространственных и временных искусств в создании хореографического образа, в частности, установлении глубинной взаимосвязи изобразительного и музыкального искусства. В этом контексте было исследовано индивидуальную творческую манеру и уникальный стиль известных украинских сценографов, композиторов, музыкантов и хореографов. Выводы. Создание высокопрофессионального хореографического образа средствами пространственных и временных искусств является чрезвычайно сложным творческим процессом. В нем ощутимо сотрудничество режиссера, композитора, сценографра и балетмейстера. В этом контексте важное значение занимает не только индивидуальное, но и коллективное творчество тех художников, которые причастны к созданию хореографического образа в соответствии с возможностями и средствами тех видов искусств в рамках которых они творят. Следует также отметить, что совершенный пластический язык изобразительного искусства совмещенный с музыкальным сопровождением и хореографической пластикой создает единый целостный образ спек-

(С) Дем'янчук А. Л., 2019

(С) Кундис Р. Ю., 2019 
такля. Важными компонентами создания художественного образа является художественный стиль и техника исполнения, сочетание традиции и новаторства. Однако исследования вопроса, касающиеся проблемы создания хореографического образа средствами пространственных и временных искусств, еще нуждаются в более глубоких исследованиях и новых научных подходах.

Ключевые слова: хореографический образ, изобразительные, словесные и музыкальные искусства; сценография; балет; народно-сценический танец.

Demianchuk Andrii, PhD in Arts, associate professor of the Department of Stage Production and Choreography of the Lviv Ivan Franko National University; Kundys Ruslan, PhD in Arts, associate professor of the Department of Stage Production and Choreography of the Lviv Ivan Franko National University

Creation of a choreographic character by means of spatial and temporal arts

The purpose of the article is to demonstrate the role of spatial and temporal arts in the creation of a choreographic character. To study the relationship between the visual and musical arts as an integral component of the ballet shows. To show the interconnection of the Ukrainian ballet theater, national folklore, and literature. Methodology. A complex of methods has been applied in the study, such as historical, comparative, typological, analysis and generalization method, descriptive, visual, artistic-stylistic (analysis of the creative manner of separate authors, their schools, and art epochs). Owing to these methods we have studied the individual creative manner of separate stage designers, composers, and ballet-masters as well as the synthesis and artistic stylistics of choreographic works. The scientific novelty of this work is in revealing the role of spatial and temporal arts in the creation of a choreographic character, particularly, in demonstration of the underlying interconnection of the visual and musical arts. In this context, we have studied the individual creative manner and the unique style of the known Ukrainian stage designers, composers, musicians, and choreographers. Conclusions. The creation of a highly professional choreographic character using spatial and temporal arts is an exceptionally complicated creative process. In this process, there can be an observed collaboration of the stage director, composer, stage designer, and ballet-master. In this context of great importance is not only the individual but also the collective creative work of the artists involved in the creation of the choreographic character in line with the opportunities and means of those types of art within whose frameworks they do their job. It should be noted that the perfect plastic language of the visual art combined with the musical accompaniment and choreographic plastic produces the whole integral image of the performance. The essential components of the creation of the artistic character are the artistic style and the performance techniques as well as the combination of tradition and pioneering work. However, the study of the points pertaining to the problem of the creation of the choreographic character using spatial and temporal arts still requires greater in-depth investigations.

Key words: choreographic character; visual, oral and music arts; stagecraft; ballet; folk-stage dance.

Актуальність теми дослідження зумовлена важливістю розкриття ролі просторових і часових мистецтв у створенні хореографічного образу. Зазначимо, що необхідною умовою створення високопрофесійного хореографічного твору є гармонійне поєднання різних видів та жанрів мистецтва, зокрема просторових (образотворчих) та часових (словесних, музичних). Хоча ці мистецтва й різняться за природою, вони взаємодіють між собою, підсилюючи одне одного. Цю синергію особливо відчуваємо в художній сценографії та музичному супроводі, які в хореографічному творі об'єднані спільною сюжетною лінією та композиційною побудовою.

Аналіз досліджень і публікацій. Про створення хореографічного образу українського балету засобами просторових і часових мистецтв, а також творчість відомих українських сценографів, композиторів, режисерів та артистів балету написано низку наукових статей та монографій [4-8; 12-23]. У цих публікаціях також знаходимо відомості про результати їхньої співпраці. Проте виявлено й малодосліджені аспекти творчості митців. Зокрема, малодослідженою $є$ художня стилістика творів та їхній синтез з іншими видами та жанрами мистецтва, а також і те, який вплив на їхню творчість мало класичне та модерне європейське мистецтво. Зазначимо, що цей вплив можливо дослідити тільки в межах конкретної історичної епохи чи періоду. Поряд з описом літературної та музичної основи хореографічних творів здійснені спроби дослідити історію, культуру, етнографію та фольклор, наголошуючи на важливості звернень до української національної традиції в контексті світової культурної спадщини. Мета статті - розкрити роль просторових і часових мистецтв у створенні хореографічного образу. Дослідити зв'язок образотворчого та музичного мистецтва як невід'ємної складової балетних вистав. Показати взаємозв'язок українського балетного театру, національного фольклору та літератури. Довести значення та важливість української національної традиції у створенні нових хореографічних творів.

Виклад основного матеріалу. Створення високопрофесійного хореографічного образу - відповідальний і надзвичайно складний процес. Це синтез творчості композитора, сценографа та балетмейстера, який нині визначається терміном «хореографічна драматургія». Необхідною умовою створення високопрофесійного хореографічного твору є гармонійне поєднання різних видів та жанрів мистецтв, зокрема, просторових (образотворчих) та часових (словесних, музичних). Синергія цих мистецтв особливо відчутна в художній сценографії та музичному супроводі, які в хореографічному творі об'єднані спільною сюжетною лінією та композицією.

Слід зазначити, що метою й призначенням будь-якого мистецького твору, також хореографічного, $є$ вища духовна сутність, у якій фарби, звуки, танець і слова стають виразними засобами творчості [11, 129]. Створюючи унікальний хореографічний образ, не слід забувати про народні танцювально-пісенні фольклорні традиції та усталені естетичні мистецькі норми, які в усі часи базувалися на ідеалах 
добра, правди й краси. А моральні цінності повинні домінувати і визначати цінності сучасного мистецтва [10, 191].

Відповідно до загальноєвропейського розуміння хореографія розглядається як сукупність двох областей - мистецтва балету й мистецтва танцю. Балет - вища театральна форма хореографічного мистецтва, у якій вона піднімається до рівня візуального музично-сценічного дійства. Український народний танець, а також народно-сценічний танець, фольк-модерн тощо поєднують сучасність 3 багатовіковою історією народу. Нині українська народна хореографія має розмаїті фрорми народних танців та похідних. Вона здійснює значний вплив на формування національної свідомості та самосвідомості [12, 47-48].

До збереження традицій та подальшого розвитку української народно-сценічної хореографії мають відношення багато визначних українських хореографів XX ст., зокрема, В. Верховинець (Костів), В. Авраменко, Я. Чуперчук, П. Вірський та ін. Без їхнього самозречення, героїзму та непосильної праці, яка охоплювала неймовірно широкий спектр діяльності (науково-дослідну, етнографічну, фольклорну, творчу режисерсько-постановочну, балетмейстерську виконавську та педагогічну діяльність тощо), сучасна народна українська хореографія не мала б такого великого наукового й творчого доробку. Без їхньої праці, яка синтезувала основи українського народного танцю, національного фольклору та строю не було б і сучасного українського балету. В. Верховинець про тодішній стан української народно-сценічної хореографії пише: «Наш балет, якщо йому судилося коли-небудь народитись, мусить бути народним, своєрідним, а таким він стане тоді, коли в нього увіллється багатство народного танцю 3 його мальовничими фігурами й широкою, нічим не обмеженою фантазією думок і коли він буде перейнятий духом веселих танцювальних пісень, повних кипучості, енергії, бадьорості та невимушеної щирої розваги справжнього народного життя» [1, 124].

Визначному українському хореографу було дуже боляче, що багатий ігровий матеріал, створений i породжений народною фантазією, поступово забувається і безслідно гине, ніким не записаний і не впорядкований. Тому в навчально-виховний процес впроваджував кращі традиції української народної творчості $[1,14]$. У хореографічних постановках Маестро намагався передати справжній національний колорит та духовність українського народного танцю. Про успішність цих постановок, зокрема, гуцульського танцю «Аркан», поставленому в опері С. Монюшка «Галька», свідчать рядки в статті на театральний сезон 1909-1910 рр.: «Ця спроба постановки серйозної опери на сцені українського театру вдалася, звичайно, якнайкраще з вокального й сценічного боку, а деякі місця, як, наприклад, танець "Аркан", були просто блискучі» [2, 17].

Досліджуючи давній український обрядовий та пісенний фрольклор, В. Верховинець вивчав український народний танець, збираючи і записуючи по селах автентичний хореографічний матеріал. Результатом цього дослідження стала перша наукова праця «Українське весілля» (1912 р.). У ній поданий повний запис народного весільного обряду з музичним додатком (понад сто сорок мелодій) [3, 71]. У 1919 р. В. Верховинець написав фундаментальну теоретичну працю «Теорія українського народного танцю», у якій систематизував й узагальнив теорію українського хореографічного мистецтва [2]. Високу оцінку цій праці дали видатні українські балетмейстери - П. Вірський, В. Вронський, Н. Скорульська, Г. Березова тощо [4, 10; 6, 467]. Це було перше в Україні ґрунтовне дослідження характеру й принципу побудови української народної хореографії, дослідження, яке мало на меті створення на народній основі національного фахового балету.

В. Верховинець прагнув захистити народний танець від поширеного на українській сцені цього періоду негативних «вульгаризаторських» тенденцій, від усього, що його змінювало чи спотворювало. Тому в 1925 р. розробив репертуарно-методичний посібник «Весняночка», у якому був поданий оброблений і систематизований пісенний та ігрововий матеріал, авторські музичні твори М. Лисенка, М. Леонтовича, К. Стеценка, П. Козицького, П. Демуцького, фольклорні записи К. Квітки, С. Титаренка, А. Конощенка, С. Дрімцова, поезії Т. Шевченка, Лесі Українки, О. Олеся, М. Вороного, Д. Загула, П. Тичини та ін. українських поетів [1; 32].

У новаторській співпраці В. Верховинця з головним балетмейстером Харківського оперного театру В. Литвиненком реалізувались нові ідеї в постановці першого українського балету «Пан Каньовський» (музика М. Вериківського). Прем'єра цього спектаклю відбулась у Харкові 19 квітня 1931 р.

У цьому ж році в Полтаві був створений жіночий колектив театралізованого співу - «Жінхоранс» (огранізатор та керівник В. Верховинець). Репертуарну основу колективу становили фольклорні пісенні, хореографічні, ігрові зразки, зокрема українські пісні «Сиділа на колодці», «Ой чия то хата біла», «Ой дівчина по гриби ходила», «Очерет лугом гуде», українські танці «Василиха», «Шевчик», «Віз», «Журавель» [2, 27], народні ігри і хороводи «Мак», «Шум», «Кривий танок», «Кроковеє колесо» [22, 190]. Цей жіночий ансамбль, одягнений у традиційні національні костюми, виконував українську пісню в супроводі ритмічних жестів та рухів відповідно до сюжету та художнього образу твору. Так постав новий жанр театралізованої пісні, який базувався на традиції українських народних танців, пісень i діалогів. У кіномистецтві цього періоду також широко використовувався український фрольклор, пісня і танець. Прикладом може слугувати кінофільм І. Кавалерідзе «Коліївщина» (1933-1934 рр., Одеська кіностудія), у якому знімався український хор під керівництвом В. Верховинця. 
Відомий український хореограф О. Голдрич зазначає, що народний танець був тісно пов'язаний 3 народною музикою та іншими видами народного мистецтва. 3 давніх-давен він був невід'ємною складовою народних свят і обрядів. Це веснянки, купальські та масляничні ігри тощо. Хороводи теж беруть свій початок у старовинних народних святах та обрядах [5, 10-11]. Зазначимо, що кращі українські театри завжди зберігали традиції народного мистецтва, розвивали й збагачували народний танець. Прикладом можуть слугувати трупи Кропивницького, Старицького, Саксаганського тощо. У XX ст. зберігали та примножували українське народне хореографічне мистецтво в Західній Україні такі видатні хореографи, як Ярослав Чуперчук, Володимир Петрик, Клара Балог, Дарій Ластівка, Анатолій Бондарев, Дана Демків та ін. [5, 47-48].

В Україні було створено багато балетних вистав, тісно пов'язаних з національною літературою та народною музикою й танцем. Прикладом може слугувати балет «Лілея» (муз. К. Данькевича, балетмейстер В. Вронський, 1940 р.), створений за мотивами творів Т. Шевченка. А також балет «Лісова пісня» (муз. М. Скорульського, балетмейстер С. Сергеев, 1946 р.), основою якого послужила казкафеєрія Лесі Українки. Старовинна дума про героїчну боротьбу українського народу з турецьким нашестям відтворена у балеті «Маруся Богуславка» (муз. А. Свечникова, балетмейстер С. Сергеев, 1951 р.).

Прикладом балетних вистав, у яких класичний танець тісно переплітається з багатством національного фольклору, можуть слугувати чотири балети на місцеву національну тематику, поставлені у Львівському оперному театрі імені І. Франка, а саме: «Сойчине крило» та «Хустка Довбуша» (муз. А. Кос-Анатольський, балетмейстер М. Трегубов, 1964 р.), «Тіні забутих предків» (муз. В. Кирейка, балетмейстер М. Трегубов, за одноіменною повістю М. Коцюбинського, 1960 р.) та балет «Орися» (муз. А. Кос-Анахольського, балетмейстер М. Заславський, 1964 р.) [5, 49].

Літературною основою балетної вистави «Сойчине крило» стала однойменна новела Івана Франка. Вона віддзеркалює нелегку жіночу долю, проблему вибору та її наслідки, змальовану автором в новітній інтерпретації. Марія - головна героїня твору, помилилася у своєму виборі, що призвело до страшних фрізичних та моральних страждань. Проте вона згадує перше кохання, і робить спробу повернути втрачені почуття. Герої твору уособлюють боротьбу між байдужим відстороненням до живих почуттів та емоцій. У цій виставі спостерігаємо творчу співпрацю композитора А. Кос-Анатольського 3 балетмейстером М. Трегубовим. Відповідно до сюжетної лінії твору у виставі подана проблема стосунків між чоловіком та жінкою, засудження помилок, за які неминуче приходить розплата. Парадоксально, але тільки втративши можна усвідомити цінність втраченого. Проте головним лейтмотивом твору є возвеличення кохання як найвищого облагороджуючого почуття [9].

Танцювальний балет «Хустка Довбуша» (1951) був присвячений визвольній боротьбі західноукраїнських селян проти панів під проводом Олекси Довбуша $[17,29]$. У хореографічній постановці відчутний синтез класичної хореографії та сценічні фрорми гуцульського народного танцю, а також правдиві та енергійні людські характери. Для молодого Львівського театру прем'єра цього нового балету була безпрецедентною подією, ознаменувавши широке використання в балетній практиці гуцульського національного вбрання, танцю та фольклору. Це був яскравий приклад плідної співпраці режисера та артистів [21, 29]. Проте новий варіант постановки (1953 р.), «безсумнівно, став ціліснішим і переконливішим», зайнявши почесне місце в репертуарі театру [17, 30; 23, 11-12].

У хореографії важливе значення надається музичному мистецтву. I це не випадково, адже тисячолітній розвиток світової культури підтверджується надзвичайно тісним зв'язком цих видів мистецтва. Музичний супровід не слід розглядати як звичайний ритмічний супровід, що полегшує виконання рухів. Його добір має відповідати характеру та змісту танцювальної постановки. Для народних і класичних танців використовують народну музику, обробки народних мелодій, а також надбання вітчизняної і зарубіжної класичної спадщини М. Глінки, П. Чайковського, М. Римського-Корсакова, Л. Деліба, А. Адана, Л. Мінкуса, а також Р. Глієра, С. Прокоф'єва, Б. Асаф'єва, А. Хачатуряна та ін. [5, 157, 160]. У цьому контексті слід відзначити колективну творчість артистів балету. Їхній індивідуальний виконавський стиль і майстерність стають вихідним моментом у створенні художнього образу.

Не менш важливим, а подекуди і вирішальним чинником, який впливає на створення хореографічного образу є художньо-стилістичні особливості епохи, чи історичного періоду. Так, наприклад, у мистецтві XX ст., поряд з класичним, співіснують й нові модерністські напрямки - авангарду, конструктивізму, символізму тощо. У мистецтві української сценографії в першій третині XX ст. у виставах з'являється так званий сценічний конструктивізм (В. Бобрицький, В. Дьяков, М. Калмиков, Б. Косарєв, М. Міщенко, Б. Цибіс) [20, 13]. Авангардні сценічні конструкції проектували В. Меллер, А. Петрицький, О. Хвостенко-Хвостов, Г. Цапок, В. Шкляєв, М. Симашкевич та ін. [9, 42]. А в мистецтві другої третини XX ст. художники почали використовувати європейський досвід відеопроекцій та освітлювальну техніку $[19,44]$.

Щоб краще розуміти проблеми, які поставали перед митцями у втіленні власних ідей, слід поглянути на часові й просторові межі їх творчості. Загально відомо, що на території колишнього Радянського Союзу в 30-70-х рр. XX ст. існував міцний ідеологічний напрямок соціалістичного реалізму (т. зв. «соцреалізм»), у якому мистецтво було підпорядковане правлячій у цей період комуністичній ідеології. 
Мистецтво, зокрема засоби та форми вираження мистецького образу, підлягали жорстокій цензурі. Багато творів було знищено, а їхніх виконавців - репресовано.

Прикладом може слугувати заборонена опера «Цвіт папороті» Є. Станковича (Київ, 1978). На той час це був новий підхід у жанровому вирішенні сценічного видовища, сутність якого полягала у відношенні композитора до фольклору. Тут прадавні народні мелодії та музичні тембри поєднувалися з новими на той час модерними принципами композиторської техніки та створеними для цієї постановки монументальними живописними оформленнями.

Згідно з історичними даними, пропозицію написання цього грандіозного сценічного твору Є. Станкович отримав від французької імпресарської фрірми «Алітека» для Народного академічного хору ім. Г. Верьовки (художній керівник - А. Авдієвський) у 1977 році. За свідченням самого композитора, «були сподівання, що нарешті прийшов час, коли світовий глядач зможе побачити і почути взірець найбагатшого українського фольклору і образів, викладених сучасною музичною мовою, переосмислених композитором і постановником...» [8].

Літературною основою цієї опери стало лібрето О. Стельмашенка (до творчої команди ввійшли: художник Є. Лисик, балетмейстер А. Шекера, диригент Ф. Глущенко). А назва опери «Цвіт папороті» пригадувала стародавню народну легенду, яка стверджує, що «той, хто знайде квітку папороті в ніч на Івана Купала, буде щасливим...». Метою цього замовлення було змінити імідж художніх колективів Радянського Союзу, до яких втрачався інтерес за кордоном. У цій фольк-опері Є. Станкович наповнив давні зразки народної музики сучасним звучанням. «Всі три дії сприймались як вокально-оркестрові сюїти, в яких переплітаються народні фольклорні зразки з авторською музикою композитора. Органічне злиття автентики з оригінальним композиторським стилем відбулося завдяки глибинному проникненню майстра в найдавніші шари народного музичного мистецтва і поєднання особливостей фольклору з сучасними засобами композиторського письма, композиторської техніки. Твір писався для народного хору і симфонічного оркестру - такого в ті роки ще ніхто не робив» [16].

Проте після перегляду у київському палаці «Україна» ця опера була заборонена, а унікальну сценографію, яку до неї створив відомий львівський сценограф Євген Лисик, було знищено. Символьнометафоричні монументальні живописні горизонти, створені львівським Маестро, вдало поєднані 3 елементами народно-міфологічних зображень, музичним супроводом та емоційним виконанням характерних народних танців. Мистецтвознавці, досліджуючи вцілілі ескізи й замальовки до цієї опери, відзначають цікаве поєднання академічного та народного живопису, яке утворило новий національний стиль [22, 21-24]. Для цієї вистави сценограф намалював чотири монументальні живописні полотнагоризонти на кожну пору року. У них мистецькими засобами було втілено певну ідею. Наприклад, у композиції «Зима» в центрі знаходився велетенський терновий вінок, у композиції «Весна» було розміщено три дерева, на яких у гніздах сиділи діти зі свічками, які нагадували ангелів [18]. Також встановлено, що вони створені з урахуванням гармонійних законів. У центрі композиції першого ескізу, в еліпсі, символі нескінченності зображено чарівну водойму - життєво-творчу силу українського народу, а пропорції радіусів центрів еліпса дорівнюють пропорції золотого перетину. Композиція другої завіси вписана в еліпс. У ній історія українського народу відтворена символьно-метафорично: у міфологічних персонажах, подіях, символах та астрологічних знаках [14, 81-82].

Були й інші невдалі спроби поставити цю оперу (у 1998 році разом із швейцарськими художниками Хуго Широм і Томасом Бірве на Міжнародній виставці у Швейцарії; з диригентом В. Василенком у Донецьку) [8]. Прем'єра цієї опери під назвою «Коли цвіте папороть» у програмі «Український прорив» відбулася у Львівській Національній Опері 15-17 грудня 2017 р. [15].

Надзвичайно цінною є опера-балет «Створення світу» А. Петрова (Мінськ, 1987 р.). Для цієї опери Євген Лисик створив високо-духовний образ Мадонни (Марії і Дитятка). Створений після чорнобильської трагедії, образ підносить вічну загальнолюдську тему жертовності та материнства [14, 81-82].

Зображення Мадонни з Дитям вписане в коло - символ вічності. На інших полотнах закомпонована евольвента кола (спіралеподібна крива, що описується прямою лінією) [14, 82].

Композитор А. Петров так згадує співпрацю з львівським сценографом Є. Лисиком: «Чим більше я дивився виставу, тим більше мені подобались його декорації ... Він акцентував драматичні та фрілософські моменти балету і тим самим надав спектаклю ще більш значущого і об'ємного звучання». Музику до прем'єри цього балету у Львові композитор А. Петров написав за мотивами малюнків французького художника Жана Еффеля. Про них сам художник сказав, що «книжка моїх малюнків - поема уславлення людини-творця» $[7,23]$.

Хоча сюжет балету (лібрето «Створення світу» Н. Касаткіної та В. Васильова за редакцією В. Єлізар'єва та Є. Лисика) й відходить від біблійного тексту, проте в ньому залишене головне - безмежна любов Бога - Творця всесвіту до своїх створінь Адама і Єви. Про свою роботу над сценографією до цієї постановки Є. Лисик говорив: «Образотворчому мистецтву так само, як і музиці й хореографії, треба надати можливість зробити для вистави максимум можливого. Або все - або мовчати». Маестро також створював екскізи сценічних костюмів, які давали акторам поштовх до перевтілення. Проектуючи костюми для балетів, не «вивітрював з них духу сучасності, навіть якщо вони були історичними» [7, 23-24]. 
У постановках 70-80-х рр. весь сценічний простір підпорядковувався асоціативно-метафоричним модулям. А досконала мова образотворчого мистецтва поєднана з музичним супроводом та хореографічною пластикою створює єдиний цілісний образ вистави, яка емоційно впливає на глядача, не залишаючи байдужим. Важливими компонентами у створенні образу є художній стиль і техніка виконання. Можна констатувати також і те, що в кращих мистецьких творах завжди вдало поєднані традиція та новаторство.

У відродженні українського народно-сценічного танцю важливе значення надавалося автентичному збереженню народних танців, музиці, театрально-декораційному оформленню, зокрема, національному одягу, як важливому елементу хореографічної постановки. Велике значення художньому оформленню концертних програм як невід'ємному компоненту спектаклю надавав відомий український хореограф П. Вірський, який для здійснення своїх задумів залучав кращих художників. Відомо про його плідну співпрацю з київським сценографом А. Петрицьким, творча мова і стилістика якого має свої особливості. Його театральні декорації - це авторська інтерпретація у створенні та доповненні сюжету новим сценічним образом, побудованим на українській національній традиції.

Підсумовуючи, зазначимо, що творення хореографічного образу засобами пластичних та часових мистецтв - відповідальний і складний процес. Це спільна творчість багатьох людей, основними з яких $є$ композитор, балетмейстер та сценограф. Створений ними художній образ вистави, який є основою хореографічного твору, повинен емоційно впливати та викликати у глядача своєрідний «катарсис» (очищення), і нікого не залишити байдужим.

\section{תimepamypa}

1. Верховинець В. М. Весняночка. 5-е вид. Київ: Муз. Україна, 1989. 342 с.

2. Верховинець В. М. Теорія українського народного танцю. 5-е вид. Київ: Муз. Україна, 1990. 152 с.

3. Верховинець В. М. Українське весілля. Етнографічний збірник товариства імені Т. Г. Шевченка. Кн. 1. Київ, 1912. С. 71-168.

4. Вронський В. Передмова до третього видання. Верховинець В. М. Теорія українського народного танцю. Київ: Муз. Україна, 1990. С. 10.

5. Голдрич О. Хореографрія: Посібник з основ хореографічного мистецтва та композиції танцю. Вид. друге, доповнене. Львів: Сполом, 2006. 172 с.

6. Дем'янко Н. Ю. Василь Миколайович Верховинець (1880-1938). Персоналії в історії національної педагогіки. 22 видатних українських педагоги: підруч. [А. М. Бойко, В. Д. Бардінова та ін.]; під заг. ред. А. М. Бойко. Київ: ВД Професіонал, 2004. С. 460-489.

7. Доманська Г., Проскуряков В. Те, що живе у тобі... Кіно-Театр. № 1. 1997. С. $22-24$.

8. Євген Станкович «Цвіт папороті» (феєрія опера-балет). Львівська національна опера. Львів, 20 жовтня 2017. URL: https://opera.lviv.ua/tsvit-paporoti/ (дата звернення: 15.06.2019).

9. І Іван Франко. Зібрання творів [у 50 т.]. Т. 16. Київ: Наукова думка, 1978.

10. Маритен Ж. Ответственность художника. Самосознание европейской культуры XX века: Мыслители и писатели Запада о месте культуры в современном обществе. Москва: Политиздат, 1991. 366 с.

11. Назар Н. Споглядати улюбленого. Жовква: Місіонер, 2016. 320 с.

12. Підлипська А. Народно-сценічний танець як засіб впливу на національну свідомість самосвідомість. Вісник Львівського університету. Серія мист-во. 2015. Вип. 16. Ч. 2. С. 156-160.

13. Плахотнюк О. Синтез мистецтва джаз-танцю і живопису: спорідненість, взаємовплив. Вісник львівської національної академії мистецтв. - Вип. 32. - Львів: ЛНАМ, 2017. С. 115-120.

14. Проскуряков В., Климко З., Зінченко О. Творчість Є. М. Лисика в часі, просторі, сценографії та архітектурі: монографія. Львів: Видавництво Львівської політехніки, 2016. 136 с.

15. Сенишин О. У Львові - світова прем'єра фольк-опери Є. Станковича «Коли цвіте папороть». Zaxid.net. $\begin{array}{lr}15 & \text { грудня, } \\ 2017 .\end{array}$ https://zaxid.net/u_Ivovi_svitova_premyera_folk_operi_stankovicha_koli_tsvite_paporot_n1444260 (дата звернення: 15.06.2019).

16. Степанченко Г. У пошуках «цвіту папороті». Культура - dt.ua. (21 листопада, 2003). URL: https://dt.ua/CULTURE/u_poshukah_tsvitu_paporoti. html (дата звернення: 15.06.2019).

17. Терещенко А. Львівський театр опери та балету імені Івана Франка: піввіковий творчий шлях. Київ: Музична Україна, 1989. 208 с.

18. Титаренко М. Євген Лисик: нестерпна легкість (не?)буття. 85-літтю дня народження геніального львівського сценографа присвячується. Zbruc. 2015. 10 жовтня URL: https://zbruc.eu/node/42420 (дата звернення 05.02.2018).

19. Триколенко С. Українська сценографрія кінця XX - початку XXI ст.: основні тенденції розвитку та авторські позиції: дис. ... канд. мистецтвознавства: 26.00.01. Інститут мистецтвознавства, фольклористики та етнології ім. М. Рильського. Київ, 2016. 211 с. 1980. $131 \mathrm{c}$

20. Френкель М. Современная сценография. Некоторые вопросы теории и практики. Киев: Мистецтво,

21. Хустка Довбуша. Прем'єра балету лауреата Сталінської премії А. Кос-Анатольського у Львівському театрі опери та балету. Вільна Україна. 31 березня, 1951.

22. Челомбитько Г. Новые спектакли. Опера-балет «Вий» В. Губаренко в Одесском театре оперы и балета. Советский балет. 1985. № 1. С. 21-24.

23. Чурпіта Т. Не народний, але заслужений: маловідомі сторінки творчої біографії Миколи Трегубова. Танцювальні студії: зб. наук. пр. Вип. 1. М-во освіти і науки України, М-во культури України, Київ. нац. ун-т культури і мистецтв. Київ: Вид. центр КНУКіМ, 2018. С. 6-16. 


\section{References}

1. Verkhovynets, V. (1989). Vesnyanochka. 5th edition. Kyiv: Musical Ukraine [in Ukrainian].

2. Verkhovynets, V. (1990). Theory of Ukrainian folk dance. 5th edition. Kyiv: Musical Ukraine [in Ukrainian]

3. Verkhovynets, V. (1912). Ukrainian wedding. Ethnographic collection of the T. Shevchenko Society. Part 1, pp. 71-168. Kyiv [in Ukrainian].

4. Vronskyi, V. (1990). Preface to the third edition. Verkhovynets V. Theory of Ukrainian folk dance. Kyiv: Musical Ukraine, p. 10 [in Ukrainian].

5. Holdrych, O. (2006). Choreography. Basics of choreographic art and dance composition. Second Edition, Supplemented. Lviv: Spolom [in Ukrainian].

6. Demianko, N. (2004). Vasyl Verkhovinets (1880-1938). Persons in the history of national pedagogy. 22 prominent Ukrainian educators: a textbook [A.M. Boyko, V. D. Bardinov and others.]; under the edit AM Boyko. Kyiv: VD Professional. pp. 460-489 [in Ukrainian].

Ukrainian]

7. Domanska, H., Proskuriakov, V. (1997). What lives inside you... Picture theater. Part 1, pp. 22-24. [in

8. levhen Stankovych «Flower of the Ferns» (opera ballet)] Lviv National Opera (October 20, 2017) Lviv. Retrieved from https://opera.Iviv.ua/tsvit-paporoti/ [in Ukrainian].

9. Ivan Franko (1978). Ivan Franko. Collected works [in 50 vol.]. Vol. 16. Kyiv: Scientific Opinion [in Ukrainian].

10. Mariten, Zh. (1991). Responsibility of the artist. Self-awareness of European culture of the 20th century: Thinkers and writers of the West about the place of culture in modern society. Moscow: Politizdat [in Russian].

11. Nazar, N. (2016). Contemplate the beloved. Zhovkva: Missionary [in Ukrainian].

12. Pidlypska, A. (2015). Folk-stage dance as a means of influencing national consciousness and selfawareness. Visnyk of Lviv University. Series art. Iss. 16. Part 2, pp. 156-160 [in Ukrainian].

13. Plakhotniuk, O. (2017). Synthesis of jazz-dance and painting art: affinity, mutual influence. Visnyk of the Lviv National Academy of Ar. Lviv: LNAM. Iss. 32, pp.115-120 [in Ukrainian].

14. Proskuriakov, V., Klymko, Z. \& Zinchenko, O. (2016). The creativity of Yevhen Lysyk in time, space, scenography, and architecture: monograph. Lviv: Published by Lviv Polytechnic [in Ukrainian].

Zaxid.net.

15. Senyshyn, O. (2017). In Lviv - the world premiere of folk opera by E. Stankovych «When bloom fern»

https://zaxid.net/u_Ivovi_svitova premyera folk operi stankovicha koli_tsvite_paporot n1444260 [in Ukrainian].

16. Stepanchenko, H. (2003). In search of "flower of ferns". Culture. 21 November. Retrieved from https://dt.ua/CULTURE/u_poshukah_tsvitu_paporoti.html [in Ukrainian].

17. Tereshchenko, A. (1989). The Lviv Opera and Ballet Theater named after Ivan Franko: The half-century creative way. Kyiv: Music Ukraine [in Ukrainian].

18. Tytarenko, M. (2015). Yevhen Lisik: Unbearable ease (not?) Being. The 85th birthday of the genius Lviv scenographer is dedicated]. Zbruc, October, 10. Retrieved from https://zbruc.eu/node/42420 [in Ukrainian].

19. Trykolenko, S. (2016). Ukrainian scenography of the late $20^{\text {th }}$-early $21^{\text {st }}$ centuries: the main tendencies of development and authorship positions. The dissertation of the candidate of art criticism: 26.00.01. Institute of Art Studies, Folklore Studies and Ethnology named after M. Rylsky. Kiev, [in Ukrainian].

20. Frenkel, M. (1980). Modern scenography. Some questions of theory and practice. Kiev: Arts. [in Russian].

21. Khustka Dovbusha. A premiere of the ballet of the winner of the Stalin Prize of A. Kos-Anatolsky at the Lviv Opera and Ballet Theatre. (1951). Free Ukraine. March, 31 [in Ukrainian].

22. Chelombitko, G. (1985). New performances. Opera-ballet «Viy» V. Gubarenko in the Odessa Opera and Ballet Theater. Soviet ballet. Issue 1, pp. 21-24 [in Russian].

23. Churpita, T. (2018). Not folk, but deserved: little-known pages of Mykola Trehubov's creative biography. Dance studios: collection of scientific works. Issue 1: Ministry of Education and Science of Ukraine, Ministry of Culture of Ukraine, Kyiv National University of Culture and Arts. Kyiv: Publishing Center KNUKiM, pp. 6-16 [in Ukrainian]. 